\title{
Challenging and potentially dangerous times
}

(an NCTE news release)

Members of the National Council of Teachers of English have elected Sheridan Blau, professor of English and education at the University of California at Santa Barbara, to serve as vice president. (Blau, who also directs the South Coast Writing Project and who serves on the National Writing Project Advisory Board, will take office during NCTE's 85th Annual Convention in San Diego, California, will become president-elect a year later, and will assume the presidency at the 1997 Annual Convention.)

A former high school English teacher in Trenton, New Jersey, Blau is the author of numerous articles on composition theory and the teaching of composition and literature, and on professional development for teachers. He is a senior research associate with the National Research Center on Literature Teaching and Learning and is the director of the National Literature Project Network. Within NCTE, Blau is a member of the Standing Committee on Testing and Evaluation and serves on the executive committee of NCTE's Conference on English Education.

Blau believes humanities educators are facing challenging and potentially dangerous times, with what he terms the traditional goals and content of literary study being hotly debated within both political and educational circles. At the same time, he says, individual parents and watchdog groups are attempting to control what children are reading and writing in schools based on their own views about what is ideologically acceptable, rather than what is educationally sound.

"Much of the current debate represents much-desired parental involvement in education and overdue public disgust at scenarios of gross bureaucratic mismanagement of educational resources," Blau says, adding that the threat to English education does not come from the debate itself or from possible reallocations of public resources that result from thoughtful deliberations. "The danger lies not in dissent but in a descent from reasoned civil discourse to propagandistic bullying. Policy decisions shaped by the rhetoric of self-righteousness rather than reasoned debate cannot serve the public interest and will not command public respect."

Blau applauds the assistance NCTE currently offers to teachers and schools facing irresponsible censorship attempts and would like to see the Council's efforts to defend literacy and academic freedom broadened.

- The National Council of Teachers of English (NCTE), the world's largest subject-matter educational association, is dedicated to improving the teaching and learning of English and the language arts at all levels of education. Its membership is composed of elementary, middle, and high school teachers, supervisors of English programs, college and university faculty, teacher educators, local and state agency English specialists, and professionals in related fields.

\section{Terrible events}

In his July 95 editorial HARRY BRENT, Editor of the Quarterly Review of Doublespeak, made the following observations on doublespeak as used in the heated American debate on abortion:

Some readers have asked me what I thought the most important doublespeak topic of the year. This is a hard question to answer, but if pressed I would probably have to point to the language used in the debate surrounding abortion, since in the context of that debate several people have been murdered by antiabortion zealots. $Q R D$ readers may have noted that the runners up for the Doublespeak Award last year included some anti-abortion activists who equated abortion with murder and who thus concluded that "murderers" should themselves be murdered. Although this material appeared in the January issue of $Q R D$, the award itself was given the previous November, and the nomination (which I myself wrote and submitted) was written in September, well before a series of new acts of violence against abortionists, including murder, took place. I do not want to sound like Louis Rukeyser who likes to say "I told you so" about the stock market, and I would gladly have all of this material erased from QRD if any one of the individuals who were killed could be brought back to life. But it is almost as though this 
publication said that we "told you so," that the irresponsible and malicious language used in the abortion debate, principally, but not exclusively, by the opponents of abortion, had at least helped somewhat to create a climate in which murder of one's political opponents became the order of the day.

These terrible events prompt me to make this appeal in $Q R D$ : can we not alter the language that we use in speaking about abortion so that we can discuss the issue in a calm, civil way? Might I suggest for starters that both sides in the debate drop their self-descriptive labels: Right to Life and Pro-Choice. Both terms are doublespeak. The abortion opponents beg the question, and the abortion supporters sidestep it. In he first instance, it is by no means clear that an embryo or fetus is an actual human being, at least not from the instant of conception. Even St. Thomas Aquinas in his Summa Contra Gentiles argues that the embryo and fetus go through stages of "vegetable" and "animal" development before becoming human. In the second instance, the issue is not the right of women to generally exercise free will, a proposition that almost everyone in the modern civilized world would support, but that women be free to have abortions. Imagine applying the slogan "a woman's right to choose" to infanticide. Clearly "choice" is not the issue.

The point here is that both sides have decided to get an edge on each other by manipulating language, specifically by enlarging the semantic field of the issue. The anti-abortion groups want to make it seem that if one is for eliminating even the least developed forms of the embryo, then one is against human life, perhaps against all life. The pro-abortion groups want to make it seem that if one is against a woman's right to choose to have an abortion, then one is against a woman's right to have a choice about anything at all.

\section{The OED's NARP}

(from the OED News, the newsletter of The Oxford English Dictionary, Series 2, No. 2, Jun 95)

Dr JFFREY TRIGGS, Director of the OED North American Reading Programme, describes how it works

Even before the publication of OED2 in 1989, the editors in Oxford recognized the need for more immediate access to North American sources and began planning to develop Oxford's first official North American Reading Programme based on American soil. In fact, in preparing the original $O E D$, James Murray had benefited considerably from an unofficial North American reading programme directed by Professor March at Lafayette College.

On a number of occasions, most prominently in his well-known preface, Murray directed special praise at his American readers. During the period of the four-volume Supplement to the OED (1972-86), American sources were widely read, but as part of the $O E D$ 's reading programme based in Oxford. The fanfare that attended the publication in 1989 was quietly accompanied by another first for the $O E D$ : the establishment of its new American office in Morristown, New Jersey, and the recruitment and training of its first official readers in America. The North American Reading Programme, in part because of the circumstances of its creation, has been associated with a number of other 'firsts' as well.

From the very beginning, it broke with the tradition of having readers 'card' their quotations on the venerable six-by-four inch slips of paper. Beginning with its first 84 quotations in August 1989, NARP (as it came to be known) has produced all its quotations in electronic form. As the NARP readers have always been scattered geographically across a large continent, it was necessary to invent from scratch a flexible system of data entry that enabled people with different equipment and computer backgrounds to contribute to what was to become an exceptionally accurate and homogeneous quotation database.

Instead of writing out quotations by hand, NARP readers used highlighters to mark their catchwords and then either keyed in the texts with a word processor or text editor, or sent them to be keyed by trained keyboarders. The resultant files in a simple 'template' format were then converted automatically at a central location to structured electronic 'slips' in SGML format. In this manner, the NARP was able to grow within two years from a programme producing hundreds of quotations per month to one that regularly produces anywhere from twelve to sixteen thousand electronic slips per month. To date, NARP has sent over 760,000 quotations to Oxford, each of these averaging over twenty words of searchable text. These 